\title{
THE INFLUENCE OF ORGANIZATIONAL CULTURE, WORK ETHIC, AND EMPLOYEE DISCIPLINE ON THE ORGANIZATIONAL PERFORMANCE AT THE REGIONAL LAND OFFICE OF WEST PAPUA PROVINCE IN MANOKWARI
}

\author{
Besse Faradiba* \\ Institut Agama Islam Negeri Parepare, Sulawesi Selatan, Indonesia \\ *Corresponding author: bessefaradiba@iainpare.ac.id
}

\begin{abstract}
This research seeks to examine (1) the effect of organizational climate on the effectiveness of organizational performance. (2) the effect of work ethic on the effectiveness of organizational performance. (3) the effect of work discipline on the effectiveness of organizational performance (4) the effect of organizational climate, work ethic, and work discipline on the effectiveness of organizational performance in the selected site; Regional Land Office of West Papua. Performance measurements were carried out as the survey of the Regional Autonomy Implementation Monitoring Committee (KPPOD) revealed that the timeframe for the issuance of land certificates was below the average time of other regions. This research employed multiple linear regression analysis using convenience sampling or purposive sampling with a proportional quota of 53 respondents. Descriptive analysis was performed in data analysis to describe the results of the research. Multiple linear regression (quantitative data) analysis was applied to see the influence of organizational culture, work ethic, and employee work discipline on the effectiveness of the performance of the employee of the Regional Land Office of West Papua in Manokwari. The results informed that there was a joint influence of organizational culture, work ethic, and work discipline on the effectiveness of organizational performance. The $F$ test results showed that the sig value was smaller than the t-table. Employee coaching and training were required to improve employee's performance. Besides, further research that investigates other contributing variables on the effectiveness of the organizational performance is also needed.
\end{abstract}

Keywords: organizational culture; work discipline; performance effectiveness; work ethics.

Received June ${ }^{5 \text { th }} 2020$

Revision June 25 th 2020

Accepted for Publication July ${ }^{10 t h} 2020$

\section{INTRODUCTION}

The land is considered crucial for the majority of the Indonesian people whose composition of society and economy is agrarian in nature. People's access and rights to the land have opened up chances to improve their socio-economic well-being. This also helps increase people's dignity and fulfill their basic rights. The National Land Office (BPN) of the Republic of Indonesia was formed based on Presidential Decree Number 26 of 1988, which was amended to 
Presidential Decree Number 34 of 2003, and was replaced with the Presidential Regulation Number 10 of 2006, which includes the National Land Office as a non-departmental public body that is under and is responsible to the president.

The Regional Land Office of West Papua Province is part of the National Land Office that serves the community in the land sector. This office is expected to contribute significantly to improving people's welfare through land management and regulation. Land services are also part of an integrated effort to develop human resources to realize a developed and independent nation and state (Robertus, 2009). In the land sector, the improvement of the quality of land services should be supported by high-quality employees. One of the government's endeavors to improve the quality of land office employees is through the development of human resources.

A survey by the KPPOD on the Regional Economic Governance Index in 2012 revealed that the average time required to obtain a land certificate is two months. There were 12 regions out of 243 regions that needed more than six months to issue the certificates namely Sorong (26 weeks), Manokwari (27 weeks), Kaimana Regency (36 weeks), and Fak-Fak (42 weeks). While in Makassar, the average time needed was 9 weeks (www.suarakarya-online.com). The longest duration spent on a land certificate experienced by the Fak-Fak residents. After waiting for about one year, 128 heads of the family received their certificates for the ex-autonomous area that they had inhabited for decades. The mass land registrations were carried out independently by the applicant. The total certified area of land is $11,000 \mathrm{~m}^{2}$. Each area varies in size, from $24 \mathrm{~m}^{2}$ to $100 \mathrm{~m}^{2}$. (www.suaramerdeka.com)

By referring to the results of the survey by the KPPOD, it is obvious that the average time required to obtain a land certificate is two months. However, Manokwari, one of the cities in West Papua should wait for 26 weeks for the land certificate. The delay of the issuance of this land certificate is a problem at BPN. Several factors might have contributed to this condition, such as the status of the land (in conflict) that made it hard to record or else the employees' performance which includes organizational culture, work ethic, and employee discipline had made the land certification processes less optimal. These problems encouraged the researcher to conduct research on the influence of organizational culture, work ethics, and work discipline on the employee's performance at the Regional Land Office of West Papua.

\section{LITERATURE REVIEW \\ Organizational culture}

The experts interpret organizational culture as a physical element, where culture can be seen as an attribution of the organization or as an attribution of the individual's perception. Simamora, (2001) opined that organizational culture is an internal environment or organizational psychology. Organizational culture influences the practices and policies of human resources (HR) that are accepted by members of the organization.

In this present research, the researcher adopts the definition of organizational culture proposed by Pines as mentioned above. 


\section{Work Ethic}

Every organization that strives to make progress needs to empower and develop its employee. Work ethic is one of the media to improve the quality of the employee. Julie (2004) interpreted ethics as a fundamental attitude towards self and the surroundings and work are more specifically defined as a commercial endeavor that becomes a necessity for life, or something imperative of oneself and related to a sacred self-identity. The self-identity contained in it is derived from religious demands.

From these points, it is concluded that the work ethic is a basic attitude both before, during, and after work. For the purpose of this research, work ethic would refer to Pandji Anoraga's statements as mentioned above.

\section{Work Discipline}

Aluko (2003) mentioned that the issue of work discipline is a problem that needs to address by any institution as discipline affects the effectiveness and efficiency of the operation of the organization. In addition, Greenberg and Baron (1993) underpinned the importance of punishment in building discipline. The discipline of employees can be interpreted as a form of adherence to one's behavior in complying with certain provisions or regulations relating to work and enforced in an organization or company (Subekti D., 2001). Thus, employee discipline is a form of obedience that can affect the effectiveness of the performance of the employee of the Regional Land Office of West Papua. The definition of the term used in this research referred to the definition proposed by Byars and Rue.

\section{Performance Effectiveness}

Aluko (2004) said that effectivity illustrates the input-process-output cycle. Whereas Bambang (2004) defined performance as one's ability to complete his tasks and accomplish his goals. Therefore, it can be concluded that the effectiveness of organizational performance is a cooperation of individuals within the organization which involved the input-process-output cycle to achieve the expected goals.

The followings aspects describe the interaction takes place at the Regional Land Office of West Papua Province:

a. This organization includes input-process-output

b. The organization experiences mutual relations with several parties.

Therefore, the effectiveness of organizational performance is the accomplishment of goals through individual cooperation.

\section{Conceptual Framework}

This present research investigates the influence of organizational culture, work ethics, and employee discipline on the effectiveness of employee performance at the Regional Land Office of West Papua ". The influence was viewed from organizational performance in achieving its goals. 
The following diagram shows the conceptual framework of this research.

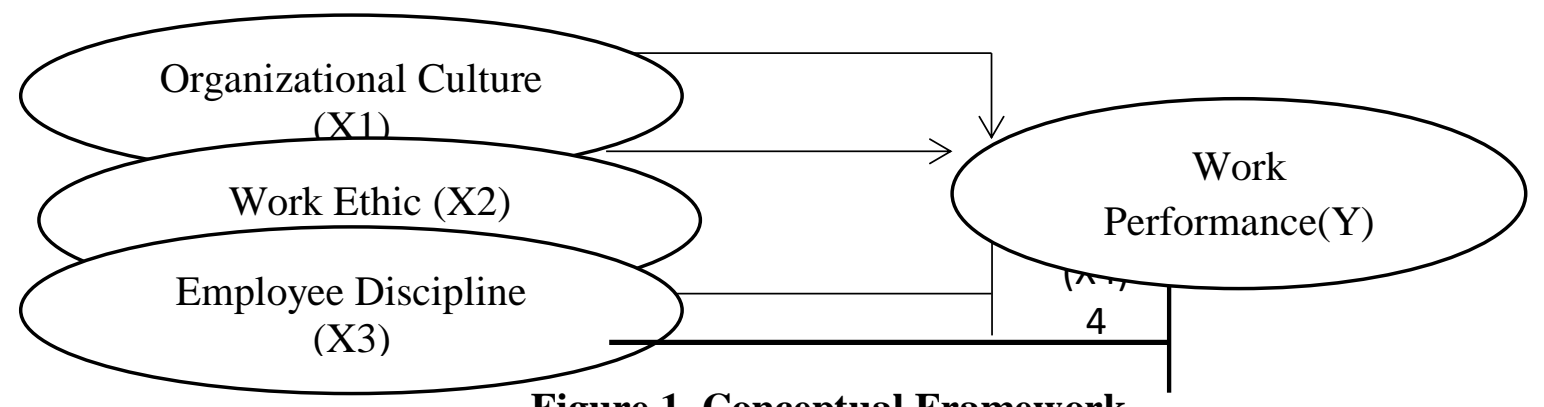

Figure 1. Conceptual Framework

The diagram is explained as follows::

1. The variable $\mathrm{X}$ is an independent variable:

a. X1 includes organizational culture, the indicators studied are workload, work harmony, cooperation, and regulations.

b. X2 contains work ethic, the indicators are work assessment results and work beliefs; work as an activity, work needs perseverance and works as a form of worship.

c. X3 deals with employee discipline, the indicators are punctuality, time of service, adherence to discipline, and compliance with superior.

d. X4 is organizational culture, work ethic, and employee discipline.

2. The variable $\mathrm{Y}$ is the dependent variable, which is the effectiveness of the organizational performance of the Regional Land Office of West Papua whose indicators are productivity and utilization.

By considering the framework above, this research analyzes the influence of organizational culture, work ethics, and employee discipline on the effectiveness of the performance of the employee at the Regional Land Office of West Papua.

\section{Hypotheses}

There are several hypotheses proposed in this research:

1. Organizational culture influences the effectiveness of employee performance at the Regional Land Office of West Papua

2. Work ethic influences the effectiveness of employee performance at the Regional Land Office of West Papua

3. Work discipline influences the effectiveness of employee performance at the Regional Land Office of West Papua

4. Organizational culture, work ethic, and work discipline affect the effectiveness of employee performance at the Regional Land Office of West Papua. 


\section{METHODOLOGY}

Table 2. Sampling Size

\begin{tabular}{|c|l|c|c|}
\hline No & \multicolumn{1}{|c|}{ Respondent } & Proportion & Sample \\
\hline 1 & Administrative & 20 & 10 \\
\hline 2 & Survey, Measurement and Mapping Division & 24 & 12 \\
\hline 3 & Land Rights and Land Registration Division & 29 & 13 \\
\hline 4 & Land Management and Arrangement Division & 18 & 8 \\
\hline 5 & Land Control and Community Empowerment Division & 14 & 7 \\
\hline 6 & The investigation and Handling of Land Disputes and Conflicts Division & 5 & 3 \\
\hline
\end{tabular}

source: employee attendance archives of BPN Regional Office of West Papua

\section{Data Analysis}

The technique of Analyzing the Data

a. Descriptive statistics

This statistical test aimed to determine the number, mean, and the percentage of the variables of this research.

b. Multiple linear regression analysis

Multiple regression was used to measure the influence of organizational culture, work ethics, and employee discipline on employee's performance at the Regional Land Office of West Papua Province.

\section{RESULTS AND DISCUSSION}

\section{Results}

1. Variable Description

a. Organizational Culture

Table 3. The Distribution of the Respondents' Answer on Organizational Culture

\begin{tabular}{|rl|r|r|r|r|}
\hline & Frequency & Percent & Valid Percent & $\begin{array}{c}\text { Cumulative } \\
\text { Percent }\end{array}$ \\
\hline Valid & 2 & 2 & 3.8 & 3.8 & 3.8 \\
& 51 & 96.2 & 96.2 & 100.0 \\
& Total & 53 & 100.0 & 100.0 & \\
\hline
\end{tabular}

Source: the results of data processing

Where: 2 = Satisfactory

$3=$ Good 
Table 3 above informs that 51 respondents (96.2\%) agreed that the organizational culture in the Regional Land Office of West Papua was in good category and the rest 2 respondents $(3.8 \%)$ said that it was in satisfactory category.

b. Work Ethic

Table 4. The Distribution of the Respondents' Answer on Work Ethic

\begin{tabular}{|cc|c|c|c|c|}
\hline & Frequency & Percent & Valid Percent & $\begin{array}{c}\text { Cumulative } \\
\text { Percent }\end{array}$ \\
\hline Valid 3 & 53 & 100.0 & 100.0 & 100.0 \\
\hline
\end{tabular}

source: the results of data processing

Where: $3=$ Good

From table 4 it is obvious that all 53 respondents (100\%) said that the work ethic of the employees at the Regional Land Office of West Papua was in a good category.

c. Work Discipline

Table 5. The Distribution of the Respondents' Answer on Work Discipline

\begin{tabular}{|c|c|c|c|c|c|}
\hline & & Frequency & Percent & Valid Percent & $\begin{array}{c}\text { Cumulative } \\
\text { Percent }\end{array}$ \\
\hline \multirow[t]{4}{*}{ Valid } & 1 & 3 & 5.7 & 5.7 & 5.7 \\
\hline & 2 & 5 & 9.4 & 9.4 & 15.1 \\
\hline & 3 & 45 & 84.9 & 84.9 & 100.0 \\
\hline & Total & 53 & 100.0 & 100.0 & \\
\hline
\end{tabular}

source: the results of data processing

Where: $1=$ Poor

$2=$ Satisfactory

$3=$ Good

Table 5 features that views on the work discipline of the employees at the Regional Land Office of West Papua Province were varied. 45 respondents (84.9\%) said that it was in a good category, 5 respondents $(9.4 \%)$ in the satisfactory category, and 3 respondents $(5.7 \%)$ scored it in the poor category.

\section{d. Work Effectiveness}

Table 6. The Distribution of the Respondents' Answer on Work Effectiveness

\begin{tabular}{|rl|r|r|r|r|}
\hline & Frequency & Percent & Valid Percent & $\begin{array}{c}\text { Cumulative } \\
\text { Percent }\end{array}$ \\
\hline Valid & 2 & 11 & 20.8 & 20.8 & 20.8 \\
& 42 & 79.2 & 79.2 & 100.0 \\
& Total & 53 & 100.0 & 100.0 & \\
\hline
\end{tabular}

source: the results of data processing 
Where $: 2=$ Satisfactory

$3=$ Good

Table 6 shows research participants' responses toward work effectiveness at the Regional Land Office of West Papua Province. 42 respondents (79.2\%) considered that the work effectiveness at this institution was in a good category, while the rest 11 respondents $(20.8 \%)$ said it was at a satisfactory level.

\section{Data Normality Test}

The results of the normality test using the Kolmogorov-Smirnov test on the four variables showed that data are normally distributed (Sig> 0.05). The followings are the results of the test: organizational culture $(\mathrm{p}=0.070)$, work ethic $(\mathrm{p}=0.142)$, work discipline $(\mathrm{p}=0.956)$, effectiveness of performance $(\mathrm{p}=0.670)$.

3. Hypothesis Test Analysis

a. Descriptive Statistics Test

Table 7. The Results of Descriptive Statistics Test

\begin{tabular}{|l|r|r|r|r|r|}
\hline & N & Minimum & Maximum & Mean & Std. Deviation \\
\hline Organizational_Culture & 53 & 29 & 44 & 39.43 & 3.805 \\
Work_Ethic & 53 & 46 & 52 & 48.38 & 1.712 \\
Work_Discipline & 53 & 26 & 56 & 45.02 & 7.752 \\
Performance_Effective & 53 & 12 & 31 & 25.83 & 4.358 \\
ness & 53 & & & & \\
Valid N (listwise) & & & & \\
\hline
\end{tabular}

source: the results of data processing

Table 7 informs that the mean score of the effectiveness of organizational performance is 25.83 with a standard deviation of 4.358 . The mean of organizational culture is 39.43 with a standard deviation of 3.805 . Work ethic 48.38 with a standard deviation of 1.712 and work discipline 45.02 with a standard deviation of 7.752 .

b. T-test

The results of the t-test are presented in the table below.

Table 8. T-test Results

Coefficients $^{\mathrm{a}}$

\begin{tabular}{|c|c|c|c|c|c|}
\hline \multirow[b]{2}{*}{ Model } & \multicolumn{2}{|c|}{ Unstandardized Coefficients } & $\begin{array}{c}\text { Standardized } \\
\text { Coefficients }\end{array}$ & \multirow[b]{2}{*}{$\mathrm{t}$} & \multirow[b]{2}{*}{ Sig. } \\
\hline & $B$ & Std. Error & Beta & & \\
\hline $1 \quad$ (Constant) & -2.946 & 2.305 & & -1.278 & .207 \\
\hline
\end{tabular}




\begin{tabular}{|c|c|c|c|c|}
\hline $\begin{array}{l}\text { Organizational_C } \\
\text { ulture }\end{array}$ & 1.988 & .328 & .333 & 2.236 \\
\hline Work_Ethic & 2.119 & .797 & .369 & 2.659 \\
\hline Work Discipline & 2.027 & .548 & .225 & 2.185 \\
\hline
\end{tabular}

source: the results of data processing

From table 8 it is known that the organizational culture regression coefficient has a positive value of 1.988. This means that the organizational culture has a positive effect on the effectiveness of performance. The value of sig. $<0.05(0.004<0.05)$ or t obtained $(2.236)>t$ table $(2,000)$. Thus, it is concluded that organizational culture influences the dependent variable (effectiveness of organizational performance) significantly.

Work ethic has a regression coefficient value of 2.119. This indicates that it has a positive influence on the effectiveness of performance where the value of sig $(0.011<0.05)$ or $t$ obtained (2.659)> $\mathrm{t}$ table (2,000). The next independent variable, work discipline, has a regression coefficient of 2.027. Work discipline has a positive effect on the effectiveness of performance with sig $0.008<0.05$ or $\mathrm{t}$ obtained $(2.185)>\mathrm{t}$ table $(2,000)$. So, the work discipline has a significant effect on the dependent variable (performance effectiveness).

c. F Test

The results of the $\mathrm{F}$ test are presented in the following table.

Table 9. The Results of the F Test

\begin{tabular}{|c|c|c|c|c|c|c|}
\hline \multicolumn{7}{|c|}{$\mathbf{A N O V A}^{\mathbf{b}}$} \\
\hline & Model & Sum of Squares & Df & Mean Square & $\mathrm{F}$ & Sig. \\
\hline 1 & Regression & 2.400 & 3 & .800 & 26,68 & $.007^{\mathrm{a}}$ \\
\hline & Residual & 15.883 & 49 & .324 & & \\
\hline & Total & 18.283 & 52 & & & \\
\hline
\end{tabular}

source: the results of data processing

Table 9 presents that the calculated $\mathrm{F}$ value is $26.68>\mathrm{F}$ Table $(26.35)$ or sig $0.007<0.05$. This means that all independent variables influence performance effectiveness.

d. Test of the Coefficient of Determination $\left(\mathrm{R}^{2}\right)$

$\mathrm{R}$-Square $=0.131$ means that $13.1 \%$ of the variation of the variables in the performance effectiveness can be explained by organizational culture, work ethic and work discipline, while the rest $(100 \%-13.1 \%=86.9 \%)$ is explained by other factors not included in the model.

e. Predictor Contribution

1) Effective Contribution (SE\%)

a) Organizational Culture (x1) 


$$
\begin{aligned}
& \mathrm{SE}(\mathrm{x} 1) \%=\beta \times 1 \mathrm{X} \mathrm{rxy} 1 \mathrm{X} 100 \% \\
& =1,998 \times 0,327 \times 100 \%=6,55 \%
\end{aligned}
$$

b) Work Ethic (x2)

$$
\begin{aligned}
& \mathrm{SE}(\mathrm{x} 2) \%=\beta \times 2 \times \mathrm{rxy} 2 \mathrm{X} 100 \% \\
& =2,119 \times 0,100 \times 100 \%=2,12 \%
\end{aligned}
$$

c) Work Discipline (x3)

$$
\begin{aligned}
& \mathrm{SE}(\mathrm{x} 3) \%=\beta \times 3 \times \mathrm{rxy} 3 \mathrm{X} 100 \% \\
& =2,185 \times 0,020 \times 100 \%=4,43 \%
\end{aligned}
$$

The results of the calculation shows that the total effective contribution is $6,55 \%+2,120 \%+$ $4,43 \%=13,1 \%$.

2) Relative Contribution (SR\%)

a) Organizational Culture (x1)

$$
\mathrm{SR}(\mathrm{x} 1) \%=\frac{S E(x 1) \%}{R^{2}}=\frac{6,55 \%}{13,1 \%} \times 100 \%=50 \%
$$

b) Work Ethic (x2)

$$
\operatorname{SR}(\mathrm{x} 2) \%=\frac{S E(x 2) \%}{R^{2}}=\frac{2,12 \%}{13,1 \%} \times 100 \%=16,18 \%
$$

c) Work Discipline (x3)

$$
\operatorname{SR}(\mathrm{x} 3) \%=\frac{S E(x 3) \%}{R^{2}}=\frac{4,43 \%}{13,1 \%} \times 100 \%=33,82 \%
$$

The score of relative contribution is $50 \%+16,18 \%+33,8 \%=100 \%$

f. Regression Equation $\mathrm{Y}=0,131+0,333 \mathrm{X} 1+0,369 \mathrm{X} 2+0,225 \mathrm{X} 3+€$, where $\mathrm{Y}=$ the effectiveness of performance , $\mathrm{X} 1=$ organizational culture, $\mathrm{X} 2=$ work ethic and $\mathrm{X} 3=$ work discipline.

\section{Discussion}

1. The Effect of Organizational Culture on the Effectiveness of Organizational Performance

The results of the data analysis test show that the value of significance is $0.004<0.05$ since the probability value is below 0.05 then $\mathrm{H}_{\mathrm{o}}$ is rejected. This means that organizational culture has a significant influence on the effectiveness of organizational performance. This can also be seen from the t-test results which show that the t-obtained is greater than t-table $(2,236>$ $2,000)$. Based on the previous respondents' answers, 51 respondents $((96.2 \%)$ agreed that the organizational culture was in good category and 2 respondents (3.8\%) said it was in satisfactory category. A conducive working climate can support the improvement of employees' performance as this situation helps the employees more focused on their tasks.

\section{The Effect of Work Ethic on the Effectiveness of Organizational Performance}

The results of the data analysis test show that the influence of work ethic on performance effectiveness is 2.119 with a significance level of $0.011<0.05$. Because the probability value is below 0.05 then $\mathrm{H}_{\mathrm{o}}$ is rejected. This means that the work ethic has a significant influence on the effectiveness of organizational performance. This can also be seen from the t-test which shows 
that the calculated t-value is greater than t-table $(2,659>2,000)$. From the data, all respondents $(100 \%)$ considered that the work ethic of the employees at the Regional Land Office of West Papua Province was in a good category.

Work ethic is an individual's view and attitude towards work (Notoatmojo, 2003). Considering that assessment is a part of the work ethic, then, we need to know that assessment can be both positive and negative. The positive work ethic is shown by the results of the questionnaire where 27 respondents $(49.1 \%$ ) argued the work ethic of the surveyed institution was in good category and 28 respondents $(50.9 \%)$ responded that it was in satisfactory category. So, it can be assumed that a good work ethic leads to effective work performance.

\section{The Effect of Work Discipline on the Effectiveness of Organizational Performance}

The results of the data analysis test show that the influence of the work discipline on performance effectiveness is 2,027 with a significance level of 0.008 . Since the probability value $<0.05, \mathrm{H}_{\mathrm{o}}$ is rejected. It means, there is an effect of work discipline on performance effectiveness, yet it was not significant.

As an organization, the Regional Land Office of West Papua has rules and regulations regarding the duties and responsibilities of the employees. Some of these points support the manifestation of work discipline. This is supported by the description of the data showing that the work discipline of the employees at this office was in good category (45 respondents or $84.9 \%$ ), satisfactory category ( 5 respondents or $9.4 \%$ ), and poor category (3 respondents or $5.7 \%)$.

4. The Influence of Work Culture, Work Ethic, and Work Discipline on Performance Effectiveness

The results of the data analysis show that all independent variables (organizational culture, work ethic, and work discipline) influence the effectiveness of organizational performance. This can be seen in the F test results, where the F obtained (26.68) $>\mathrm{F}$ table (26.35) or the sig value $<0.05$. The results of the analysis can be presented with the following multiple linear regression equation: $\mathrm{Y}=0,131+0,333 \mathrm{X} 1+0,369 \mathrm{X} 2+0,225 \mathrm{X} 3+€$.

The coefficient of the work culture variable is 1 and is positive. A positive sign indicates a direct relationship, meaning that if the work culture increases by 1 point, then the effectiveness of the performance will rise by 0.131 points. The coefficient of work ethic is 0.333 and is positive. This means that an increase of one point of work ethic score will increase performance effectiveness by 0.333 points. The coefficient of work discipline is 0.369 and positive, this means that an increase by one point of this variable will increase to 0.369 points of the effectiveness of organizational performance.

The three independent variables are considered to have a significant influence on the effectiveness of organizational performance at the Land Office of West Papua. However, work ethic has the greatest effect compared to other variables. 
The multiple determination coefficient (R2) is 0.131 , it means that $13.1 \%$ of the factors that affect the effectiveness of the performance of the employee can be explained by organizational culture, work ethic and work discipline, while the rest $(100 \%-13.1 \%=86,9 \%)$ caused by other factors not included in the model. The relative contribution (SR\%) given by the organizational culture is $50 \%$, the work ethic $16.18 \%$ and the work discipline $33.82 \%$, and the total relative contribution is $100 \%$. Effective contribution (SE\%) set by organizational culture is $6.55 \%$, work ethic $2.120 \%$, and work discipline $4.43 \%$. Thus, to improve the effectiveness of the organizational performance, maintaining a high work discipline, a good work ethic, and a conducive working environment is pivotal. This is expected to encourage employees to improve their performance, so that, an effective organizational performance can be attained.

\section{CONCLUSIONS}

Organizational culture has a significant influence on performance effectiveness at the Regional Land Office of West Papua. The work ethic has a significant influence on performance effectiveness at the Regional Land Office of West Papua. Work discipline has a significant influence on performance effectiveness at the Regional Land Office of West Papua. There is a common influence of organizational culture, work ethic, and work discipline on performance effectiveness at the Regional Land Office of West Papua.

\section{Recommendations}

1. The Regional Land Office of West Papua needs to create and maintain conducive organizational culture, improve the work ethic and work discipline, and imbue the organizational culture, work ethic, and work discipline to the employees. These efforts can be done through coaching or training for all employees.

2. Further research is required to investigate other factors that contribute to the effectiveness of the organizational performance at the Regional Land Office of West Papua.

\section{REFERENCES}

Aarons, G. A., \& Sawitzky, A. C. (2006). Organizational Culture and Climate and Mental Health Provider Attitudes Toward Evidence-Based Practice. Psychological Services, 3(1), 61-72.

Aluko, M. A. O. (2003). The Impact of Culture on Organizational Performance in Selected Textile Firms in Nigeria. Nordic Journal of African Studies, 12 (2): 164179.

Bambang, G. (2007). Kinerja Unit-unit Kerja Fakultas Pertanian Universitas Gadjah Mada Yogyakarta. From: http://arc.ugm.ac.id/files/Abst_(0008-H- 2008).pdf.

Barkah. (2002). Pengaruh Gaya Kepemimpinan dan Budaya organisasi terhadap Prestasi Kerja Organisasi di Surabaya. Tesis. Program Pascasarjana Unair, Surabaya.

Darmanto, B. 2004. Pengaruh Motivasi Kerja dan Lingkungan Kerja terhadap Produktifitas Kerja Pegawai PT. Danaremen Muka Semarang.Jurnal Manajemen Sumber Daya Manusia. Vol 1, No.3, hlm. 20-68. 
Djokomoeljanto, R. J. S. (2009). Peranan Endokrinologi Dalam Menunjang Pembangunan Kesehatan Nasional. Retrieve 5 Mei 2009. From http://eprints.undip.ac.id/173/

Keke, T. (2005). Kompensasi Kerja, Disiplin Kerja dan Kinerja Guru SMP Kristen BPK Penabur Jakarta. Jurnal Pendidikan Penabur, 4 (4): 1-16.

Michael, C. G. D. (2003). Does Organizational Climate add to Service Quality in Hotels?. International Journal of Contemporary Hospitality Management, 15 (4), 206 - 213.

Muhadjir, J. I. (2002). Organisasi dan Manajemen. Edisi Keempat. Jakarta

Nitisemito, A. S. (2003). Manejemen Personalia, Erlangga, edisi revisi, Jakarta.

Notoatmojo, S. (2003). Pengembangan Sumberdaya Manusia. Penerbit PT Rineka Cipta, Jakarta.

Patricia. W. S., Michael I. H., Penny, F., Mark, L., Timothy, P., Douglas, R., Jill, S.C., Nicholas, W., Eric. S. W. (2004). Organizational Climate of Staff Working Conditions and Safety-An Integrative Model. Columbia University School of Nursing. from http://www.ncbi.nlm.nihgov/ books/bv.fcgi?rid=aps.section.3614

Setiaji, B. (2004). Panduan Riset Dengan Pendekatan Kuantitatif. Surakarta : Program Pasca Sarjana Universitas Muhammadiyah Surakarta.

Soehardi, S. (2003). Perilaku Organisasi. Yogyakarta: Fakultas Ekonomi Sarjanawiyata Tamansiswa Yogyakarta.

Sugiyono. (2004). Metode Penelitian Administrasi. Bandung : CV Alfabeta.

Sugiyono. (2009). Statistika untuk Penelitian. Bandung : CV Alfabeta

Suprihanto, J., Harsiwi, A. M., \& Hadi, P. (2003). Perilaku Organisasional. Yogyakarta : Sekolah Tinggi Ilmu Ekonomi YKPN.

Winarsunu, T. (2004). Statistik Dalam Penelitian Psikologi dan Pendidikan. Malang: Penerbit Universitas Muhammadiyah Malang. 